\section{FUTURE OF THE SOCIAL SCIENCES}

A CONFERENCE of social scientists, convened $A$ by the Association of Scientific Workers, was held on December 14 at Gas Industry House, London, S.W.1. Mr. J. R. M. Brumwell took the chair, and the chief speakers were Prof. S. Zuckerman, Dr. G. Wagner, Mr. Dennis Chapman and Mr. $R$. Innes. The chairman recalled the meeting held in October 1945, at which a Joint Sciences Committee had been set up to foster relations between workers in the natural and social fields of science. The Committee had functioned successfully, and, as a direct result of its activities, an increased awareness of the links between natural and social science had spread throughout the Association of Scientific Workers. In August 1946, the functions of the Committee were assumed by the Science Policy Committee of the Association. This step was taken to avoid duplication of effort because the work of the two groups soon began to overlap. The Joint Sciences Committee was provisionally reconstituted as a Social Sciences Committee to concentrate on problems of organisation and development of the social sciences themselves. Social scientists in the Association had become more conscious of their own problems of recruitment and training. It was now proposed to set up a national section of the Association of Scientific Workers representing social scientists throughout the United Kingdom.

The terms of reference of this group were : first, to advise on policy in regard to the social sciences; second, to advise on conditions of work and employment of social scientists; third, to stimulate the recruitment of social scientists into the Association; and fourth, to suggest ways of ensuring adequate representation of social scientists on committees of the Association.

Prof. Zuckerman spoke of the value of scientific discipline in social affairs and in the objective study of human institutions. He quoted with approval some observations made by Mr. Herbert Morrison in his Hobhouse Memorial Lecture, which revealed a sympathetic appreciation of the potentialities of social science. He went on to discuss the Clapham Report and, while admitting that the Report suffered from certain shortcomings, maintained that they were not so serious as some of its crities seemed to suppose. The Clapham Report marked a step forward though, possibly, a short step and not the great stride desired by the critics. It was the first official recognition of the existence of the social field of research. In Prof. Zuckerman's view the chief obstacle to progress in this field lay in the shortage of trained research workers. Hence he stressed the need for establishing a body to determine priorities for pursuing research in the social sciences. In the present state of knowledge such a body could perform a more valuable service than a Social Science Research Council, if such were set up.

Prof. Zuckerman drew a distinction, in the light of his war-time experience, between the tactics and strategy of social operations. Operational research during the War had its roots in the need to solve tactical problems as exemplified in the field of radar. But as the War advanced, the work of operational research stations, in the Army and Navy as well as in the Royal Air Force, began to impinge upon problems of strategy as well. The needs of peace likewise opened up possibilities of a dual tactical and strategical approach. Tactical problems arose, for example, in the fields of traffic, output per worker, management, incentives, selection of personnel, and building processes, all of which required investigation 'on the spot'. He remarked that in connexion with the building programme, research of this type was proceeding apace, and it was possible to control the chief variables. But such problems should be dis. tinguished from the more fundamental strategical problems involving the selection of alternative policies or courses of action. The task of scientific workers was not merely to 'clean-up' problems arising out of a situation not of their own making, but to play a part in creating the social situation. As yet, natural sciences had not become involved in the strategy of social operations; but research which commenced with a tactical aim might acquire a strategic value. Thus Prof. Bernal's studies of air raid effects began with the.aim of assessing the protective properties of shelters. They developed into a basis for offensive strategy by providing data on the dislocation of social and industrial life resulting from air attack. In this way, scientific method came to influence the choice of a major line of policy. In peace-time, economists, in particular, hadanimportant strategical part to play, for policy might be directly determined on the basis of the data provided by them. In the epoch of planning into which we were entering, science had an important strategical function to perform.

Research in the social sciences was, in his view, expensive as, for example, in carrying out social surveys. With the present shortage of trained manpower, however, and the organisational difficulties, it was, in fact, difficult to spend large sums of money on research. Housing surveys were now 'limping along' for lack of trained workers to carry them out. There was an urgent need for more social surveys to illumine policy.

An important factor in stimulating the development of the social sciences was the attitude of administrators. It was essential that administrators should acquire an appreciation of the use of scientific method in human affairs. Experience in operational research had taught that a genuine scientific attitude on the part of the investigator mattered more than training in a particular field of science. On occasion, arts graduates without a specific training in science had proved their worth in this field.

The future for the social sciences, he went on to say, must be viewed in the light of the academic background, the number of trained workers available, the adequacy of the methodology, the various fields of application and the opportunities for ad hoc tactical and fundamental strategical approaches.

In summing up, Prof. Zuckerman concluded that the outlook for the social sciences was 'very rosy'. Authorities in the field of social action were more ready now to listen to the advice of men of science. Nothing could therefore prevent further expansion.

Mr. R. Innes outlined the organisation of the Association of Scientific Workers. There were seven national sectional committees, including, for example, chemistry and engineering and metallurgy. It was proposed that the terms of reference of the provisional social sciences committee would carry over to a new national committee. Members of the Association in different parts of Great Britain who were active in the field under consideration would be linked together through the national committee, which should be widely representative of interested members. 
Mr. Dennis Chapman made a strong plea for the expansion of social research. The position of the social sciences, he said, had been transformed by the publication of the Clapham Report. There were two main fields of activity. First, there was the field of fundamental research. Here, he thought, the position was lamentably backward. Brilliant generalizations of two or three decades ago by Patrick Geddes, the Webbs, Graham Wallas and others had lain dormant for want of initiative to follow up with research. Over a wide potential range of social problems research was, at present, non-existent. No inquiries were being undertaken on such subjects as human relations in industry and politics, the family, the church and other institutions or on the social process of education. No studies were being made of the social psychology of morale, civil and industrial, or into the medical and nursing services of Britain. No one had yet attempted to study the curious distribution of civic vitality in different cities. The methods employed to-day in social research needed revitalizing. They had not advanced since the days of Charles Booth and Beatrice Webb. Many of the techniques were thirty or forty years old and needed bringing up to date. In the United States the methods of social measurement had made far more rapid progress.

In the applied field, the position was much the same. Little research was being pursued. Yet every administrative action was a social experiment and threw up problems for investigation. Social processes were constantly changing and creating experimental situations. It was untrue to assert that there were no experiments in the social field. On the contrary, social scientists were overwhelmed by the multiplicity of experiments taking place around them.

The situation as regards the status and salaries of soeial scientists left much to be desired. In the universities, status was good but the salary of the few engaged in the 'sweated trade' of social research was appreciably below that of a teacher with similar qualifications in the same subject. In Government Departments, on the other hand, there was no settled status for social scientists. Many were regarded as administrators or as statisticians; scope for publishing results of official research was also severely restricted. It would be disastrous, he thought, if all financial support for social research went to the universities. Almost every important advance in social research, so he declared, had taken place outside the universities. There was a strong case for setting up a Social Science Research Council.

During the ensuing discussion, a number of important points came to light. In Government Departments, it was said, personnel work failed to be accorded adequate recognition. It was a neglected service to be run by officers of the clerical grade without appropriate training. Another speaker challenged Prof. Zuckerman's assumption that scientific method influenced administrative decisions in sufficient measure; a great deal more 'pre-decision' analysis was needed. In this connexion, he mentioned that the Social Sciences Committee had set up a special group to study the requirements of a scientific public administration.

A third speaker reminded the meeting that it was not the function of the Association to carry out research for which full-time investigators properly financed were required. But the Association could survey a field so as to indicate the kind of research and scientific organisation that were needed. What the Association had attempted to do for fuel and power could be done for the field of social inquiry. The main weakness at the moment was a deficiency in fundamental knowledge of social phenomena. He did not regard as adequate the suggestion in the Clapham Report that provision for social research in the universities should be determined by a subcommittee of the University Grants' Committee. Opportunities should be left open for the talented individual with an inquiring mind. Universities, Government departments and other institutions should not monopolize research. Anyone who had ideas for research and could convince a small authoritative body of their value should be given sufficient financial aid to carry out the necessary inquiries. If such steps were taken the large number of workers with experience in operational or social research would have an opportunity of proving their worth. This speaker also directed attention to the need for studying the effects of advances in the social and economic research upon the development of technique in the physical sciences. We were well aware of the impact of science on society. What was now needed was a consciousness of the reciprocal influence.

Several speakers criticized the tacit assumption of the Clapham Report that all social research was expensive. It was often implied, it was said, that most social inquiries involved questionnaires on a large and costly scale. The need for 'penetration' studies of the individual, of the kind made in social anthropology, tended to be overlooked. Measurement was not a sine qua non of social research. There was a complete absence to-day of really fundamental social research, with the possible exception of industrial psychology.

Before the meeting drew to its close, a national sectional committee of the Association of Scientific Workers was set up with the terms of reference as described above, and the members duly elected.

\section{JOHN COHEN}

\section{BRITISH CONTRIBUTION TO RADIOLOCATION}

$\mathrm{E}^{\mathrm{A}}$ ARLY in March 1946, the Institution of Electrical Engineers held a Radiolocation Conference at which were presented a large number of lectures and papers by various members and other individuals who had contributed to the development and application of radiolocation during the war years. The Convention was formally opened at an ordinary meeting of the Institution by the Minister of Supply, Mr. John Wilmot, and was followed by a lecture on "The Evolution of Radiolocation" by Sir Robert Watson-Watt. In the course of this lecture it was explained that the object of the Convention was to describe and discuss British activities in this subject, which began in February 1935 and were at first conducted independently of any similar work elsewhere. Following the co-operation established between Great Britain and the United States in the autumn of 1940, later developments were conducted on the basis of a United Nations' system for which the name 'radar' was adopted in 1943, this term being then in current use in the United States.

The opening meeting referred to above was followed by twelve special meetings of the Radio Section of the Institution devoted to lectures and 